\title{
Pengaruh Konsentrasi Pupuk Daun dan Zat Pengatur Tumbuh (ZPT) Terhadap Pertumbuhan dan Hasil Tanaman Pakcoy (Brassica rapa L.) Menggunakan Sistem Budidaya Akuaponik Rakit Apung
}

The Effect of Foliar Fertilization Concentrations and Plant Growth Regulators on the Growth and Yield of Pakcoy (Brassica rapa L.) Plants Using the Aquaponic Cultivation System of Floating Raft

\author{
Author(s): Alifah Farida Sa'adah ${ }^{(1)}$; Firdha Narulita Alfian ${ }^{(1)}$; Parawita Dewanti ${ }^{(1)^{*}}$ \\ (1) Fakultas Pertanian, Universitas Jember \\ * Corresponding author: parawita.faperta@unej.ac.id
}

\section{Submitted: 02 Jun $2021 \quad$ Accepted: 18 Jul $2021 \quad$ Published: 30 Sep 2021}

\begin{abstract}
ABSTRAK
Akuaponik adalah integrasi dari sistem akuakultur dan hidroponik yang memanfaatkan kotoran ikan sebagai sumber hara tanaman. Input bagi tanaman hanya bergantung pada ketersediaan hara pada kolam ikan, sehingga kebutuhan hara terkadang masih kurang terpenuhi. Inovasi yang dapat diterapkan untuk mengatasi masalah tersebut yaitu dengan pemberian pupuk daun dan zat pengatur tumbuh. Penelitian ini dilakukan untuk mengetahui interaksi konsentrasi pupuk daun dan auksin yang terbaik pada tanaman pakcoy menggunakan sistem budidaya akuaponik rakit apung. Penelitian ini dilakukan menggunakan rancangan acak lengkap (RAL) faktorial dengan 2 faktor. Faktor pertama yaitu konsentrasi pupuk daun sebesar $1 \mathrm{~g} / \mathrm{L}, 2 \mathrm{~g} / \mathrm{L}$, dan $3 \mathrm{~g} / \mathrm{L}$ dan faktor kedua yaitu auksin auksin sebesar $0 \mathrm{ml} / \mathrm{L}, 1 \mathrm{ml} / \mathrm{L}, 2 \mathrm{ml} / \mathrm{L}$, dan $3 \mathrm{ml} / \mathrm{L}$. Data yang diperoleh selanjutnya akan dianalisis dengan menggunakan Analysis of Variance (ANOVA) apabila terdapat perlakuan yang berbeda nyata maka akan dilakukan uji beda Duncans Multiple Range Test (DMRT) pada taraf kepercayaan 95\%. Hasil penelitian menunjukkan bahwa perlakuan konsentrasi pupuk daun dan auksin berpengaruh nyata pada variabel bobot basah dan berpengaruh nyata pada variable tinggi tanaman, jumlah daun, bobot kering dan laju pertumbuhan. Perlakuan konsentrasi pupuk daun $1 \mathrm{~g} / \mathrm{L}$ dan auksin $3 \mathrm{ml} / \mathrm{L}$ merupakan perlakuan terbaik yang dapat meningkatkan hasil hingga 54,55\% dibandingkan dengan budidaya akuaponik tanpa pemberian pupuk daun dan zat pengatur tumbuh.
\end{abstract}

\section{Kata Kunci:}

akuaponik, pupuk daun, rakit apung

\section{Keywords:}

aquaponics,

foliar fertilizer,

floating raft

\section{ABSTRACT}

Aquaponics is an integration of aquaculture and hydroponic systems that utilize fish waste as a source of plant nutrients. The input for plants only depends on the availability of nutrients in the fish pond, so that nutrient needs are sometimes still not fulfilled. Innovations that can be applied to overcome this problem are the provision of foliar fertilizers and plant growth regulators. This research was conducted to determine the interaction between the concentration of foliar fertilizers and the best concentration of plant growth regulators in Pakcoy plants using a floating raft aquaponic cultivation system. This research was conducted using a factorial completely randomized design with 2 factors. The first factor is the concentration of foliar fertilization of $1 \mathrm{~g} / \mathrm{L}, 2 \mathrm{~g} / \mathrm{L}$, and $3 \mathrm{~g} / \mathrm{L}$ and the second factor is the concentration of plant growth regulators $0 \mathrm{ml} / \mathrm{L}, 1 \mathrm{ml} / \mathrm{L}, 2 \mathrm{ml} / \mathrm{L}$, and $3 \mathrm{ml} / \mathrm{L}$. The data obtained will then be analyzed using Analysis of Variance (ANOVA) if there is a significantly different treatment, the Duncans Multiple Range Test (DMRT) difference test will be carried out at the 95\% confidence level. The results showed that the concentration of foliar fertilizer and the concentration of plant growth regulators had a significant effect on the wet weight variable on the variables of plant height, number of leaves, dry weight and growth rate. The treatment of foliar fertilization concentration of $1 \mathrm{~g} / \mathrm{L}$ and concentration of plant growth regulators $3 \mathrm{ml} / \mathrm{L}$ were the best treatments that could increase the yield up to $54.55 \%$. 


\section{PENDAHULUAN}

Tanaman sawi merupakan salah satu jenis sayuran yang banyak diminati di Indonesia. Berdasarkan data dari (BPS, 2013) rata-rata konsumsi sawi perkapita yaitu sebesar 3,068 kg/tahun. Hasil analisa dari Badan Ketahanan Pangan (2019), ketersediaan komoditas sawi perkapita yaitu sebesar $2,33 \mathrm{~kg} /$ tahun. Hal ini dapat menunjukkan ketersediaan komoditas sawi di pasaran masih belum bisa memenuhi rata-rata konsumsi sawi perkapita. Ketersediaan lahan untuk budidaya sawi semakin tahun semakin berkurang. Data dari (BPS, 2019) selama 5 tahun terakhir (2015-2019) menunjukkan bahwa luas panen tanaman sawi semakin mengalami penurunan. Pada tahun 2017, luas panen tanaman sawi sebesar $61.133 \mathrm{Ha}$, menurun menjadi $61.047 \mathrm{Ha}$ pada tahun 2018 dan menurun lagi menjadi $60.871 \mathrm{Ha}$ pada tahun 2019. Ketersediaan lahan yang semakin berkurang tiap tahunnya dapat memunculkan masalah bagi ketersediaan tanaman sawi di pasaran. Usaha yang dapat dilakukan untuk mengatasi keterbatasan luas panen sawi salah satunya dengan cara pemanfaatan lahan yang tersedia melalui budidaya akuaponik.

Menurut (Habiburrohman, 2018), akuaponik merupakan kombinasi sistem akuakultur dan hidroponik yang saling menguntungkan. Akuaponik mengintegrasikan sistem akuakultur dan hidroponik untuk memanfaatkan kotoran ikan sebagai sumber hara tanaman. Apabila tidak termanfaatkan, maka kotoran ikan dan sisa makanan yang tidak terkonsumsi akan mengendap di bagian bawah kolam dan akan menyebabkan amonia yang berpotensi untuk meracuni ikan yang ada di dalamnya.

Menurut Andriyeni et al (2017), kadar bahan organik dan anorganik tersebut sangat tergantung pada jenis pakan yang digunakan, padat tebar budidaya ikan, dosis pakan yang dipakai, lama kegiatan budidaya dan ada tidaknya pergantian air kolam. Semakin tinggi padat tebar budidaya lele, maka semakin banyak pula pakan yang dibutuhkan, dengan demikian akumulasi sisa pakan dan kotoran lele di dalam kolam akan semakin besar pula. Kotoran yang ada di dalam kolam ikan akan mengalami perombakan oleh bakteri aerob dan anaerob sehingga dapat dimanfaatkan oleh tanaman sebagai zat hara. Kebutuhan tanaman akan zat hara yang terkandung di dalam air kolam yang bercampur kotoran dan sisa pakan ikan menjadi faktor yang sangat mempengaruhi laju pertumbuhan dan perkembangan tanaman yang dibudidayakan.

Penerapan akuaponik dapat dilakukan dengan berbagai sistem, salah satunya rakit apung. Sistem rakit apung memiliki prinsip kerja dengan meletakkan tanaman secara terapung diatas larutan nutrisi. Penggunaan sistem rakit apung pada akuaponik akan membuat akar tanaman kontak langsung dengan air kolam sehingga penyerapan hara oleh akar akan langsung dan dapat dilakukan setiap saat (Sutanto, 2015). Tanaman akan berfungsi sebagai filter vegetasi yang akan mengurai zat beracun yang terkandung di dalam air menjadi zat yang tidak berbahaya bagi ikan. Kelebihan penggunaan sistem rakit apung pada akuaponik yaitu relatif lebih mudah dalam perawatan dan tanaman tumbuh optimal karena mendapatkan pasokan nutrisi (Arifin, 2016).

Input pada sistem budidaya akuaponik hanya bergantung pada ketersediaan hara di kolam ikan. Input keharaan tanaman yang hanya bersumber dari kolam ikan membuat kebutuhan akan hara makro pada tanaman terkadang masih kurang dapat terpenuhi. Hal ini akan mengakibatkan pertumbuhan dan perkembangan tanaman menjadi terhambat. Kurangnya asupan hara makro pada tanaman juga dapat menyebabkan tanaman mudah terkena penyakit dan tingkat kematiannya menjadi lebih tinggi. Oleh karena itu, dibutuhkan suatu inovasi 
pemberian input pada tanaman supaya pada sistem akuaponik kebutuhan zat hara pada tanaman dapat terpenuhi dengan baik sehingga pertumbuhan dan perkembangan tanaman yang dibudidayakan dapat berlangsung secara maksimal (Sastro, 2015).

Inovasi yang dapat diterapkan untuk mengatasi kurangnya asupan zat hara pada tanaman yang dibudidayakan secara akuaponik yaitu dengan cara pemberian pupuk daun dan zat pengatur tumbuh (ZPT). Menurut Sastro, (2015), strategi untuk mengatasi defisiensi hara pada sistem akuaponik dapat dilakukan dengan cara memberikan pupuk yang diaplikasikan melalui daun. Pemberian pupuk daun dianggap lebih efektif dibanding pemberian pupuk pada bagian akar karena akan langsung masuk ke jaringan daun untuk diolah. Pupuk yang disemprotkan langsung ke daun akan masuk melalui stomata yang ada pada bagian permukaan daun. Hara yang masuk melalui stomata akan langsung diolah pada bagian jaringan di daun sebagai tempat pengolahan unsur hara yang diserap tanaman lalu ditransportasikan ke seluruh bagian tanaman. Pemberian pupuk daun pada konsentrasi yang tepat terhadap tanaman pakcoy dapat berdampak pada pertumbuhan dan hasil tanaman (Junia et al., 2017). Selain pemberian pupuk daun, pemberian ZPT pada tanaman juga dapat membantu dalam pertumbuhan dan hasil tanaman. Menurut (Pramita, Wandansari, Salim, \& Laksono, 2019). (2018), penambahan hormon secara eksogen akan mengakibatkan peningkatan kandungan hormon di dalam tubuh tanaman. Hal itu akan berdampak terhadap meningkatnya ukuran dan jumlah sel sehingga mempercepat proses pertumbuhan vegetatif tanaman. Salah satu jenis hormon yang berperan dalam proses pertumbuhan vegetatif tanaman berupa peningkatan ukuran dan jumlah sel yaitu auksin. Berdasarkan latar belakang tersebut, maka perlu untuk melakukan penelitian mengenai interaksi pemberian konsentrasi pupuk daun dan zat pengatur tumbuh auksin yang terbaik terhadap pertumbuhan dan hasil tanaman pakcoy (Brassica rapa L.) menggunakan sistem budidaya akuaponik rakit apung.

\section{METODOLOGI}

Penelitian ini dilaksanakan di Greenhouse Agrotechnopark Universitas Negeri Jember pada bulan Juli 2020 sampai November 2020. Alat yang digunakan dalam penelitian meliputi: instalasi rakit apung, kolam, netpot, timba, Total Dissolve Solid meter, $\mathrm{pH}$ meter, Chlorophyll Meter SPAD 502, sprayer, gelas ukur, bak semai, timbangan analitik, alat tulis, penggaris, dan kamera. Bahan yang digunakan dalam penelitian ini meliputi: benih tanaman pakcoy (Brassica rapa L.), ikan lele dengan kepadatan 300 ekor/m2, pakan ikan lele, rockwool, flannel, air, pupuk daun Gandasil D, zat pengatur tumbuh auksin, Effective Microorganisms 4 (EM4) perikanan, dan styrofoam. Pupuk daun diaplikasikan setiap 3 hari sekali dan zat pengatur tumbuh auksin setiap 7 hari sekali. Aplikasi pupuk daun dan zat pengatur tumbuh auksin dilakukan pada pagi hari. Parameter pengamatan meliputi tinggi tanaman, jumlah daun, bobot basah, bobot kering, dan laju pertumbuhan. Rancangan percobaan yang digunakan adalah Rancangan Acak Lengkap (RAL) secara faktorial yang terdiri dari 2 faktor. Faktor pertama yaitu konsentrasi pupuk daun yang terdiri dari 3 taraf perlakuan yaitu $1 \mathrm{~g} / \mathrm{L}$ (P1), 2 g/L (P2), dan 3 g/L (P3). Pemberian pupuk daun dilakukan 3 hari sekali pada pagi hari. Faktor kedua yaitu auksin auksin yang terdiri dari 4 taraf yaitu $0 \mathrm{ml} / \mathrm{L}$ (A0), $1 \mathrm{ml} / \mathrm{L}$ (A1), $2 \mathrm{ml} / \mathrm{L}$ (A2), dan $3 \mathrm{ml} / \mathrm{L}$ (A3). Pemberian zat pengatur tumbuh dilakukan 7 hari sekali pada pagi hari. Kombinasi perlakuan konsentrasi pupuk daun dan zat pengatur tumbuh auksin diulang sebanyak 
3 kali sehingga diperoleh 36 perlakuan. Data yang telah diperoleh selanjutnya dianalisis menggunakan analisis ragam dengan taraf $5 \%$ dan $1 \%$. Perbedaan antar perlakuan selanjutnya dianalisis dengan uji lanjut Duncans Multiple Range Test (DMRT) pada taraf kepercayaan 95\%.

\section{HASIL DAN PEMBAHASAN}

Berdasarkan data penelitian, diperoleh hasil nilai $\mathrm{F}$ hitung pada setiap variabel pengamatan seperti yang tercantum dalam Tabel 1. Tabel 1 menunjukkan bahwa interaksi aplikasi pupuk daun dan auksin berpengaruh nyata terhadap variabel tinggi tanaman, jumlah daun, bobot kering, dan laju pertumbuhan, sedangkan pada variabel bobot basah berpengaruh sangat nyata. Aplikasi perlakuan pupuk daun secara tunggal pada setiap variabel yang diamati memiliki hasil yang berbeda sangat nyata. Aplikasi perlakuan auksin secara tunggal pada setiap variabel yang diamati memiliki hasil yang berbeda nyata. Berdasarkan hasil tersebut, maka akan dilakukan uji lanjut pada setiap variabel yang diamati menggunakan uji beda Duncans Multiple Range Test (DMRT) pada taraf kepercayaan $95 \%$ dan $99 \%$.

Tabel 1. Pengaruh Pemberian Pupuk Daun dan Auksin Terhadap Parameter Pertumbuhan Tanaman Pakcoy

Table 1. Effect of foliar fertilizer and Auxin on Growth Parameters of Pakcoy

\begin{tabular}{|c|c|c|c|c|}
\hline \multirow[b]{2}{*}{ No } & \multirow[b]{2}{*}{$\begin{array}{l}\text { Variabel Pengamatan } \\
\text { Observation Variable }\end{array}$} & \multicolumn{3}{|c|}{$\begin{array}{l}\text { Nilai F-Hitung } \\
\text { F-Count Value }\end{array}$} \\
\hline & & $\begin{array}{l}\text { Pupuk Daun } \\
\text { (P) foliar } \\
\text { fertilizer }(P)\end{array}$ & $\begin{array}{c}\mathrm{ZPT} \\
\text { (A) growth } \\
\text { regulator } \\
(A)\end{array}$ & $\begin{array}{c}\text { Interaksi/ } \\
\text { treatment } \\
\text { interaction } \\
(\mathrm{PxA})\end{array}$ \\
\hline 1. & Tinggi Tanaman & $37,66^{* *}$ & $42,47^{* *}$ & $3,12^{*}$ \\
\hline 2. & Jumlah Daun & $35,11^{* *}$ & $49,88^{* *}$ & $2,52^{*}$ \\
\hline 3. & bobot basah & $18,16^{* *}$ & $30,71^{* *}$ & $4,56^{* *}$ \\
\hline 4. & bobot kering & $10,17^{* *}$ & $12,62^{* *}$ & $3,17^{*}$ \\
\hline 5. & Laju Pertumbuhan & $6,82^{* *}$ & $8,66^{* *}$ & $2,66^{*}$ \\
\hline
\end{tabular}

Keterangan: $* *=$ Berbeda sangat nyata, $*=$ Berbeda nyata

Notes: $* *=$ Very significantly different, $*=$ Significantly different

Penambahan aplikasi pupuk daun yang dikombinasikan dengan auksin pada tanaman pakcoy yang dibudidayakan secara akuaponik memiliki pengaruh terhadap tinggi tanaman, jumlah daun, bobot basah, bobot kering, dan laju pertumbuhan tanaman pakcoy. Air limbah budidaya lele dapat menurunkan kondisi perairan dan memberi pengaruh buruk terhadap proses fisiologis ikan. Sebaliknya air limbah lele tersebut memiliki kandungan hara yang tinggi sehingga dapat dimanfaatkan oleh tanaman sebagai sumber nutrisi untuk pertumbuhannya
(Rahmadhani et al., 2020). Kandungan jumlahnya masih kurang dapat memenuhi kebutuhan tanaman pakcoy sehingga masih perlu untuk diberikan aplikasi pupuk. Penambahan pupuk daun membuat pertumbuhan dan hasil tanaman pakcoy menjadi lebih baik karena memiliki kandungan unsur makro dan mikro yang dibutuhkan oleh tanaman. Kandungan pada pupuk daun berupa unsur makro berupa $14 \% \mathrm{~N}, 12 \% \mathrm{P}$, dan $14 \% \mathrm{~K}$, juga dilengkapi dengan unsur hara mikro berupa $\mathrm{Mg}, \mathrm{Mn}, \mathrm{B}, \mathrm{Cu}, \mathrm{Co}$, dan $\mathrm{Zn}$ (Iswanto, 2002). Kandungan pada pupuk daun 
memacu pertumbuhan tanaman pakcoy menjadi maksimal sehingga hasil yang diperoleh juga lebih maksimal. Salah satu unsur hara yang berperan penting dalam pembentukan daun adalah unsur hara nitrogen. (Erdiansyah et al., 2021) mengatakan bahwa unsur nitrogen berperan penting untuk pertumbuhan vegetatif tanaman seperti tinggi tanaman, pertumbuhan daun, batang, dan akar.

Pengaplikasian zat pengatur tumbuh akan maksimal apabila kebutuhan nutrisi tanaman telah tercukupi. Pengaplikasian auksin pada tanaman pakcoy di sistem akuaponik rakit apung yang telah tercukupi kebutuhan nutrisinya berdampak pada pertumbuhan dan hasil tanaman yang lebih baik. Aplikasi zat pengatur tumbuh atonik yang termasuk dalam zat pengatur tumbuh golongan auksin akan meningkatkan kemampuan tanaman untuk tumbuh lebih maksimal (Pakpahan, Azizah, \& Sudiarso, 2018). Menurut (Nurmala, 2003), atonik mengandung bahan aktif natrium dan fenol yaitu $\quad 0,2 \% \quad$ Naortonitrofenol $(\mathrm{C} 6 \mathrm{H} 4 \mathrm{NO} 3 \mathrm{Na}) ; 0,3 \%$ Na-paranitrofenol (C6H4NO3Na); 0,1\% Na-5-Nitroguaiakal (C7H6NO4Na); dan 0,05\% Na-2,4dinitrofenol (C6H3N2O5Na).

\section{Tinggi Tanaman}

Pertambahan tinggi tanaman dipengaruhi oleh perkembangan dan pertumbuhan sel yang ada di dalam tubuh tanaman. Sel tanaman yang semakin cepat membelah, memanjang, dan membesar maka pertambahan tinggi tanamannya juga semakin cepat. Interaksi pemberian kombinasi pupuk daun dan zat pengatur tumbuh memberikan pengaruh yang berbeda nyata terhadap variabel tinggi tanaman. Tabel 2 menunjukkan bahwa pemberian kombinasi konsentrasi pupuk daun $1 \mathrm{~g} / \mathrm{L}$ dengan auksin $3 \mathrm{ml} / \mathrm{L}$ memberikan rerata tinggi tanaman tertinggi dari taraf lainnya. Pupuk daun memiliki keunggulan dalam meningkatkan laju fotosintesis dengan cara menaikkan ketersediaan unsur nitrogen di dalam daun. sebagaimana diketahui bahwa unsur nitrogen mempunyai peranan penting dalam proses pertumbuhan vegetatif tanaman salah satunya tinggi tanaman.

Menurut (Manurung et al., 2020) tinggi tanaman merupakan salah satu bagian tanaman yang termasuk peka terhadap keadaan faktor eksternal tanaman, seperti lingkungan tumbuh dan media tumbuh tanaman, termasuk adanya pemberian pupuk dari luar. Berdasarkan penelitian (Fauzi et al. 2019), tanaman pakcoy yang diberikan pupuk dari limbah perikanan memiliki tinggi rerata $15,98 \mathrm{~cm}$. Pemberian aplikasi kombinasi pupuk daun $1 \mathrm{~g} / \mathrm{L}$ dan auksin $3 \mathrm{ml} / \mathrm{L}$ dapat meningkatkan rerata pertumbuhan tinggi tanaman hingga $26 \mathrm{~cm}$ dibandingkan dengan perlakuan lainnya. Tabel 2 menunjukkan bahwa pemberian auksin yang semakin tinggi hingga konsentrasi 3 $\mathrm{ml} / \mathrm{L}$ memberikan nilai tinggi tanaman yang lebih tinggi dibandingkan dengan konsentrasi yang lebih rendah, namun pemberian pupuk daun dengan konsentrasi yang lebih tinggi dari $1 \mathrm{~g} / \mathrm{L}$ memberikan nilai tinggi tanaman yang lebih rendah. Hal ini berkaitan dengan konsentrasi optimal yang dimiliki oleh baik pupuk daun maupun auksin yang mempengaruhi tanaman. Pemberian auksin akan memacu pertumbuhan meristematik tanaman berupa pembelahan dan pembesaran sel sehingga dapat meningkatkan tinggi tanaman (Franada et al., 2018). 
Tabel 2. Pengaruh Konsentrasi Pupuk Daun dan auksin Terhadap Tinggi Tanaman Table 2. Effect of Foliar Fertilization Concentrations and Growth Regulatory Substances Concentration on Plant Height

\begin{tabular}{ccccc}
\hline Pupuk Daun & \multicolumn{4}{c}{ ZPT Auksin/ Auxin Growth Regulatory (A) } \\
\cline { 2 - 5 } Foliar & $0 \mathrm{ml} / \mathrm{L}$ & $1 \mathrm{ml} / \mathrm{L}$ & $2 \mathrm{ml} / \mathrm{L}$ & $3 \mathrm{ml} / \mathrm{L}$ \\
\hline \multirow{2}{*}{$1 \mathrm{~g} / \mathrm{L}$} & $15,17 \mathrm{~A}$ & $19,00 \mathrm{~A}$ & $22,00 \mathrm{~A}$ & $26,00 \mathrm{~A}$ \\
& $\mathrm{~d}$ & $\mathrm{c}$ & $\mathrm{b}$ & $\mathrm{a}$ \\
$2 \mathrm{~g} / \mathrm{L}$ & $14 \mathrm{~A}$ & $15,33 \mathrm{~B}$ & $16,33 \mathrm{~B}$ & $21,83 \mathrm{~B}$ \\
& $\mathrm{~b}$ & $\mathrm{~b}$ & $\mathrm{~b}$ & $\mathrm{a}$ \\
$3 \mathrm{~g} / \mathrm{L}$ & $13 \mathrm{~A}$ & $14,5 \mathrm{~B}$ & $15,67 \mathrm{~B}$ & $17,5 \mathrm{C}$ \\
& $\mathrm{c}$ & $\mathrm{bc}$ & $\mathrm{ab}$ & $\mathrm{a}$ \\
\hline
\end{tabular}

Keterangan: Angka yang diikuti huruf berbeda menunjukkan hasil yang berbeda nyata pada UJD $\alpha 5 \%$. Huruf kapital dibaca vertikal (membandingkan konsentrasi auksin yang sama). Huruf non kapital dibaca horizontal (membandingkan konsentrasi pupuk daun yang sama) Notes: Numbers followed by different letters show significantly different results at Duncan $\alpha 5 \%$. Capital letter in vertical read (compare the same auxin concentration). Non capital letter in horizontal read (compare the same foliar fertilizer concentration)
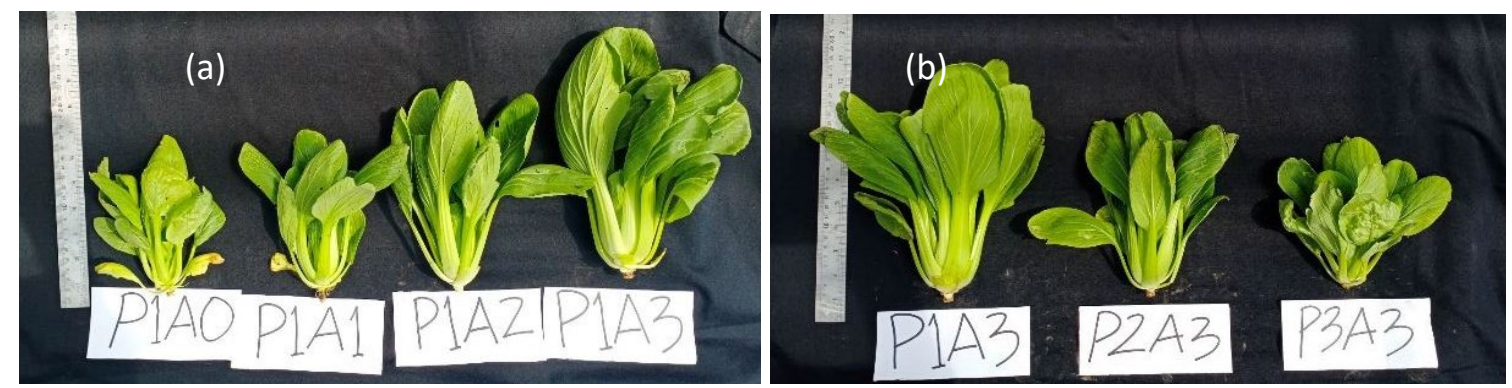

Gambar 1. Perbandingan Tinggi Tanaman.

Figure 1. Comparison of Plant Height.

Keterangan:

(a). Kombinasi Perlakuan Konsentrasi Pupuk Daun $1 \mathrm{~g} / \mathrm{L}$ dengan auksin Auksin 0, 1, 2, dan 3 ml/L, (b). Kombinasi Perlakuan auksin 3 ml/L dengan Konsentrasi Pupuk Daun 1, 2, dan 3 g/L.

Notes:

(a). Combination of $1 \mathrm{~g} / \mathrm{L}$ Foliar Fertilization Concentration with Different Plant Growth Regulators Concentrations,

(b). Combination of Plant Growth Regulators Concentration $3 \mathrm{ml} / \mathrm{L}$ with Different Foliar Fertilization Concentrations.

Penambahan pupuk daun dan auksin dengan konsentrasi yang sesuai kebutuhan tanaman dapat memberikan pengaruh yang baik pada variabel tinggi tanaman. Gambar 1A membandingkan hasil tanaman pada konsentrasi pupuk daun $1 \mathrm{~g} / \mathrm{L}$ dengan auksin yang berbeda menghasilkan tinggi tanaman terbaik pada taraf auksin $3 \mathrm{ml} / \mathrm{L}$. Penambahan auksin hingga konsentrasi 3 $\mathrm{ml} / \mathrm{L}$ pada tanaman dapat meningkatkan kandungan hormon auksin di dalam tanaman yang mendorong pertumbuhan jaringan tanaman sehingga laju pertumbuhan tanaman pada semua parameter meningkat (Muthswamy et al., 2018). Gambar 1B menunjukkan bahwa pengaplikasian pupuk daun yang semakin tinggi dapat mengakibatkan pertumbuhan tinggi tanaman menjadi terhambat. Hal ini diduga terjadi karena adanya kelebihan 
nutrisi yang diberikan ke tanaman sehingga mengganggu pertumbuhan tinggi tanaman. Lingga (2001), juga menyebutkan bahwa pemberian pupuk daun pada dosis yang berlebih dapat menyebabkan kerusakan pada tanaman, selain tinggi tanaman yang tidak meningkat gejala lain yang ditunjukkan seperti daun yang terbakar dan layu, tanaman menjadi kering, dan akhirnya gugur.

\section{Jumlah Daun}

Pembentukan daun ditentukan oleh jumlah dan ukuran sel yang ada di tanaman juga unsur hara yang diserap oleh tanaman. Interaksi pemberian konsentrasi pupuk daun dan zat pengatur tumbuh berbeda nyata terhadap variabel jumlah daun. Tabel 3 menunjukkan bahwa pemberian kombinasi konsentrasi pupuk daun $1 \mathrm{~g} / \mathrm{L}$ dengan zat pengatur tumbuh $3 \mathrm{ml} / \mathrm{L}$ memberikan rerata jumlah daun terbanyak dari taraf lainnya. Berdasarkan penelitian (Astuti \& Larasati, 2019), tanaman pakcoy yang ditanam secara akuaponik dapat menghasilkan rata-rata jumlah daun sebanyak 11,4 helai. Penambahan aplikasi konsentrasi pupuk daun $1 \mathrm{~g} / \mathrm{L}$ dan auksin 3 $\mathrm{ml} / \mathrm{L}$ menghasilkan rerata jumlah daun sebanyak 22,3 helai. Hal ini sesuai dengan pernyataan (Lestari, 2011), bahwa auksin dapat mengembangkan ukuran sel dengan cara mempengaruhi tekanan osmotik. kenaikan penyerapan air meningkat karena dinding sel yang melunak akibat kinerja auksin, hal tersebut yang menyebabkan sel mengembang. Selanjutnya auksin akan mempengaruhi proses aliran plasma selsel, membuat penyerapan pupuk yang lebih efektif, serta memberikan kekuatan vital untuk meningkatkan pertumbuhan tanaman.

Berdasarkan hasil tersebut, dapat dikatakan bahwa penambahan aplikasi pupuk daun dan zat pengatur tumbuh yang tepat dapat meningkatkan jumlah daun pada tanaman pakcoy yang di budidayakan secara akuaponik rakit apung. Kebutuhan nutrisi yang tercukupi melalui limbah kotoran lele dan aplikasi pupuk daun membuat pembentukan daun menjadi maksimal. Penambahan zat pengatur tumbuh juga memberikan bantuan untuk mengaktifkan hormon yang ada di dalam tanaman sehingga pembentukan daun dapat berlangsung lebih baik.

Tabel 3. Pengaruh Konsentrasi Pupuk Daun dan auksin Terhadap Jumlah Daun

Table 3. Effect of Foliar Fertilization Concentration and Growth Regulatory Substance Concentration on Leaf Number

\begin{tabular}{ccccc}
\hline Pupuk Daun & \multicolumn{4}{c}{ ZPT Auksin / Auxin Growth Regulatory (A) } \\
\cline { 2 - 5 } Foliar & $0 \mathrm{ml} / \mathrm{L}$ & $1 \mathrm{ml} / \mathrm{L}$ & $2 \mathrm{ml} / \mathrm{L}$ & $3 \mathrm{ml} / \mathrm{L}$ \\
\hline \multirow{2}{*}{$1 \mathrm{~g} / \mathrm{L}$} & $13 \mathrm{~A}$ & $13,7 \mathrm{~A}$ & $17,7 \mathrm{~A}$ & $22,3 \mathrm{~A}$ \\
& $\mathrm{c}$ & $\mathrm{C}$ & $\mathrm{b}$ & $\mathrm{a}$ \\
$2 \mathrm{~g} / \mathrm{L}$ & $11,3 \mathrm{~A}$ & $13 \mathrm{~A}$ & $14 \mathrm{~B}$ & $17,7 \mathrm{~B}$ \\
& $\mathrm{c}$ & $\mathrm{B}$ & $\mathrm{b}$ & $\mathrm{a}$ \\
$3 \mathrm{~g} / \mathrm{L}$ & $9 \mathrm{~B}$ & $11,7 \mathrm{~A}$ & $13 \mathrm{~B}$ & $15 \mathrm{C}$ \\
& $\mathrm{c}$ & $\mathrm{Bc}$ & $\mathrm{ab}$ & $\mathrm{a}$ \\
\hline
\end{tabular}

Keterangan: Angka yang diikuti huruf berbeda menunjukkan hasil yang berbeda nyata pada UJD $\alpha 5 \%$. Huruf kapital dibaca vertikal (membandingkan konsentrasi auksin yang sama). Huruf non kapital dibaca horizontal (membandingkan konsentrasi pupuk daun yang sama)

Notes: Numbers followed by different letters show significantly different results at Duncan $\alpha 5 \%$.

Capital letter in vertical read (compare the same auxin concentration). Non capital letter in horizontal read (compare the same foliar fertilizer concentration) 
Pemberian pupuk dapat meningkatkan jumlah ketersediaan unsur hara bagi tanaman sehingga dapat memacu peningkatan jumlah daun pada tanaman (Latarang \& Syakur, 2006). Konsentrasi pupuk daun yang tepat akan memacu perbanyakan jumlah daun pada tanaman. Pemberian konsentrasi pupuk daun yang berlebih akan menghambat pembentukan daun pada tanaman. Hal tersebut dapat terlihat pada Tabel 3 bahwa semakin tinggi pemberian konsentrasi pupuk daun maka akan menurunkan jumlah daun yang terbentuk. pada perlakuan kombinasi auksin $3 \mathrm{ml} / \mathrm{L}$ dengan pupuk daun $1 \mathrm{~g} / \mathrm{L}$ rerata jumlah daun mencapai jumlah tertinggi sebesar 22,3. sedangkan dengan adanya penambahan konsentrasi pupuk daun sebesar $2 \mathrm{~g} / \mathrm{L}$ dan $3 \mathrm{~g} / \mathrm{L}$ pada auksin yang sama yaitu $3 \mathrm{ml} / \mathrm{L}$ mengakibatkan penurunan rerata jumlah daun menjadi 17,7 dan 15. Tanaman yang diberi aplikasi hormon auksin akan memberikan respon pertumbuhan yang cepat terutama pada jumlah dan panjang daunnya, karena hormon auksin berperan dalam pembelahan sel tanaman (Amiroh, 2016).

\section{Bobot Basah}

Bobot basah tanaman dipengaruhi oleh pertambahan tinggi tanaman dan jumlah daun (Vivonda et al., 2016). Tanaman yang semakin tinggi akan memiliki jumlah daun yang semakin banyak, sehingga bobot basahnya menjadi lebih besar karena kandungan air dan hasil fotosintesis yang disimpan di dalam tanaman menjadi semakin banyak. Hal ini berpengaruh terhadap hasil tanaman yang semakin tinggi pula. Interaksi pemberian kombinasi konsentrasi pupuk daun dan zat pengatur tumbuh memiliki hasil yang berbeda nyata terhadap variabel bobot basah tanaman. Tabel 4 menunjukkan bahwa pemberian kombinasi konsentrasi pupuk daun $1 \mathrm{~g} / \mathrm{L}$ dengan zat pengatur tumbuh $3 \mathrm{ml} / \mathrm{L}$ memberikan rerata bobot basah tanaman tertinggi dari taraf lainnya.

Menurut (Siregar, 2018), tersedianya unsur hara yang cukup akan mempengaruhi kandungan klorofil pada daun pakcoy. Unsur hara yang diserap tanaman akan mengakibatkan pertumbuhan tanaman dan pembentukan klorofil maksimal sehingga proses fotosintesis berlangsung dengan baik.Berdasarkan penelitian yang dilakukan, konsentrasi pupuk daun terbaik yaitu sebesar $1 \mathrm{~g} / \mathrm{L}$. Pemberian pupuk daun yang berlebih akan berpengaruh tidak baik bagi tanaman, karena konsentrasi yang terlalu tinggi dimungkinkan akan merusak struktur kloroplas yang membuat sistem membran tilakoid dalam kloroplas akan mengalami perobekan (Mas' ud, 2009). Kumianjani et al. (2015) menyatakan bahwa perlakuan penambahan konsentrasi auksin berpengaruh nyata terhadap pembentukkan kadar klorofil, karena auksin menyebabkan DNA menjadi lebih termetilasi sehingga menyebabkan sel yang terdiferensiasi melakukan perombakan dan penyusunan ulang dari struktur sel tersebut.

Berdasarkan hasil pada Tabel 4, dapat dikatakan bahwa pemberian konsentrasi pupuk daun $1 \mathrm{~g} / \mathrm{L}$ yang dikombinasikan dengan auksin $3 \mathrm{ml} / \mathrm{L}$ menghasilkan bobot basah tertinggi. bobot basah tanaman berkaitan dengan hasil tanaman sehingga semakin besar bobot basah yang dihasilkan maka akan berpengaruh terhadap produksi yang semakin tinggi. Pemberian pupuk daun dengan konsentrasi $1 \mathrm{~g} / \mathrm{L}$ dan zat pengatur tumbuh dengan konsentrasi $3 \mathrm{ml} / \mathrm{L}$ dapat dijadikan salah satu cara untuk meningkatkan hasil tanaman pakcoy yang dibudidayakan secara akuaponik rakit apung. 
Tabel 4. Pengaruh Konsentrasi Pupuk Daun dan auksin Terhadap Bobot Basah

Table 4. Effect of Foliar Fertilization Concentrations and Growth Regulatory Substances Concentration on Wet Weight

\begin{tabular}{ccccc}
\hline \multirow{2}{*}{$\begin{array}{c}\text { Pupuk Daun } \\
\text { Foliar }\end{array}$} & \multicolumn{4}{c}{ ZPT Auksin/Auxin Growth Regulatory (A) } \\
\cline { 2 - 5 } Fertilization $(\mathrm{P})$ & $0 \mathrm{ml} / \mathrm{L}$ & $1 \mathrm{ml} / \mathrm{L}$ & $2 \mathrm{ml} / \mathrm{L}$ & $3 \mathrm{ml} / \mathrm{L}$ \\
\hline \multirow{2}{*}{$1 \mathrm{~g} / \mathrm{L}$} & $32 \mathrm{~A}$ & $42 \mathrm{~A}$ & $71 \mathrm{~A}$ & $144,67 \mathrm{~A}$ \\
& $\mathrm{c}$ & $\mathrm{C}$ & $\mathrm{b}$ & $\mathrm{a}$ \\
$2 \mathrm{~g} / \mathrm{L}$ & $27,33 \mathrm{~A}$ & $37 \mathrm{~A}$ & $44 \mathrm{~B}$ & $66 \mathrm{~B}$ \\
& $\mathrm{~b}$ & $\mathrm{~B}$ & $\mathrm{ab}$ & $\mathrm{a}$ \\
$3 \mathrm{~g} / \mathrm{L}$ & $17,33 \mathrm{~A}$ & $24,67 \mathrm{~A}$ & $43,33 \mathrm{~B}$ & $58 \mathrm{~B}$ \\
& $\mathrm{~b}$ & $\mathrm{~B}$ & $\mathrm{ab}$ & $\mathrm{a}$ \\
\hline
\end{tabular}

Keterangan: Angka yang diikuti huruf berbeda menunjukkan hasil yang berbeda nyata pada UJD $\alpha$ 5\%. Huruf kapital dibaca vertikal (membandingkan konsentrasi auksin yang sama). Huruf non kapital dibaca horizontal (membandingkan konsentrasi pupuk daun yang sama)

Notes: Numbers followed by different letters show significantly different results at Duncan $\alpha 5 \%$.

Capital letter in vertical read (compare the same auxin concentration). Non capital letter in horizontal read (compare the same foliar fertilizer concentration)
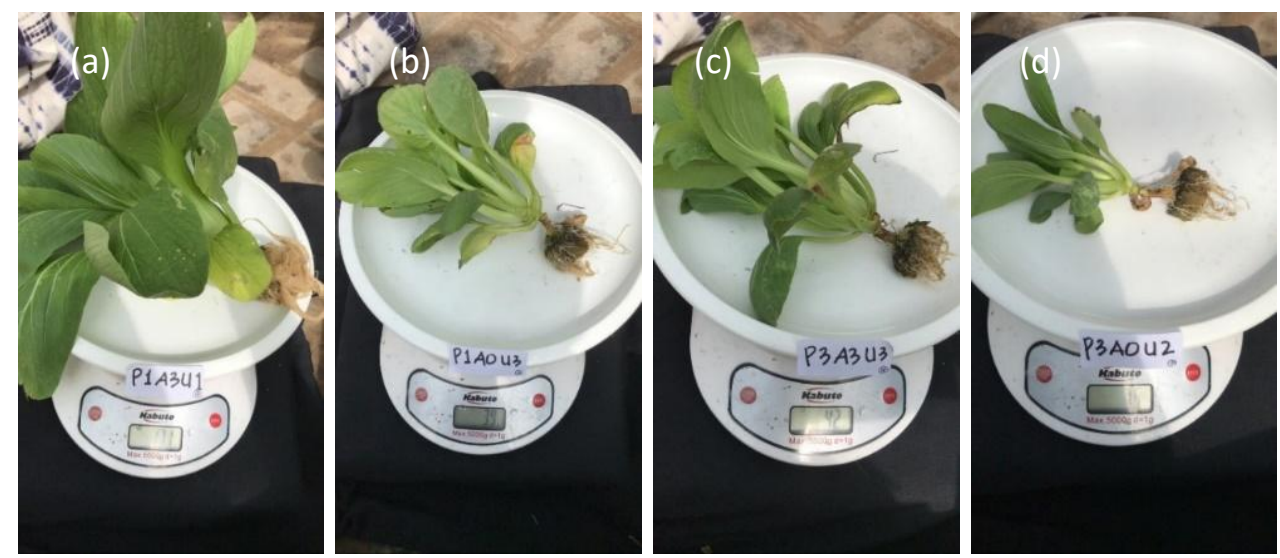

Gambar 2. bobot basah pada empat perlakuan berbeda.

Figure 2. Wet weight in four different treatments.

Keterangan:

(a). Kombinasi Perlakuan Konsentrasi Pupuk Daun $1 \mathrm{~g} / \mathrm{L}$ dan auksin $3 \mathrm{ml} / \mathrm{L}$,

(b). Kombinasi Perlakuan Konsentrasi Pupuk Daun $1 \mathrm{~g} / \mathrm{L}$ dan auksin $0 \mathrm{ml} / \mathrm{L}$,

(c). Kombinasi Perlakuan Konsentrasi Pupuk Daun $3 \mathrm{~g} / \mathrm{L}$ dan auksin $3 \mathrm{ml} / \mathrm{L}$,

(d). Kombinasi Perlakuan Konsentrasi Pupuk Daun $3 \mathrm{ml} / \mathrm{L}$ dan auksin 0 ml/L.

Notes:

(a). Combination Treatment of Foliar Fertilization Concentration $1 \mathrm{~g} / \mathrm{L}$ and Plant Growth Regulators Concentration $3 \mathrm{ml} / \mathrm{L}$,

(b). Combination Treatment of Foliar Fertilization Concentration $1 \mathrm{~g} / \mathrm{L}$ and Plant Growth Regulators Concentration $0 \mathrm{ml} / \mathrm{L}$,

(c). Combination Treatment of Foliar Fertilization Concentration $3 \mathrm{~g} / \mathrm{L}$ and Plant Growth Regulators Concentration $3 \mathrm{ml} / \mathrm{L}$,

(d). Combination Treatment of Foliar Fertilization Concentration $3 \mathrm{ml} / \mathrm{L}$ and Plant Growth Regulators Concentration $0 \mathrm{ml} / \mathrm{L}$. 
Berdasarkan penelitian (Gumelar et al., 2017), berat segar tanaman pakcoy yang dibudidayakan dengan sistem akuaponik memiliki rata-rata berat 65,75 gram. Pemberian pupuk daun yang dikombinasikan dengan zat pengatur tumbuh akan membuat pertumbuhan tanaman meningkat sehingga akan berdampak terhadap hasil. Aplikasi kombinasi antara konsentrasi pupuk daun 1 $\mathrm{g} / \mathrm{L}$ dan auksin $3 \mathrm{ml} / \mathrm{L}$ memberikan hasil bobot basah sebesar 144,67 gram. Terlihat dari perbandingan gambar 2 A,B,C, dan D bahwa kombinasi perlakuan terbaik pada tanaman pakcoy yang dibudidayakan secara aquaponik yaitu pada Gambar 2A. Gambar 2A memiliki berat segar tanaman tertinggi dibanding dengan perlakuan lainnya.

Pada tanaman sayuran, daun dan batang dimanfaatkan dalam keadaan segar, sehingga bobot basah menjadi dasar untuk menentukan kualitas tanaman tersebut.
Nutrisi yang diserap tanaman menstimulasi perkembangan organ pada tanaman yang menyebabkan peningkatan aktivitas fotosintesis dan mempengaruhi peningkatan bobot basah juga bobot kering tanaman. Ketersediaan nutrisi menjadi faktor yang sangat penting sebagai sumber energi yang berguna dalam peningkatan biomassa tanaman (Dewanti, 2015).

\section{Bobot Kering}

Bobot kering tanaman merupakan petunjuk adanya hasil fotosintesis yang dapat diendapkan setelah kadar airnya dikeringkan. Interaksi pemberian kombinasi konsentrasi pupuk daun dan zat pengatur tumbuh berbeda nyata terhadap bobot kering tanaman. Tabel 5 menunjukkan bahwa pemberian kombinasi konsentrasi pupuk daun $1 \mathrm{~g} / \mathrm{L}$ dengan zat pengatur tumbuh $3 \mathrm{ml} / \mathrm{L}$ memberikan rerata bobot kering tanaman tertinggi.

Tabel 5. Pengaruh Konsentrasi Pupuk Daun dan auksin Terhadap Bobot Kering

Table 5. Effect of Foliar Fertilization Concentration and Growth Regulatory Substance Concentration on Dry Weight

\begin{tabular}{ccccc}
\hline \multirow{2}{*}{$\begin{array}{c}\text { Pupuk Daun } \\
\text { Foliar }\end{array}$} & \multicolumn{4}{c}{ ZPT Auksin/Auxin Growth Regulatory (A) } \\
\cline { 2 - 5 } Fertilization $(\mathrm{P})$ & $0 \mathrm{ml} / \mathrm{L}$ & $1 \mathrm{ml} / \mathrm{L}$ & $2 \mathrm{ml} / \mathrm{L}$ & $3 \mathrm{ml} / \mathrm{L}$ \\
\hline \multirow{2}{*}{$1 \mathrm{~g} / \mathrm{L}$} & $2,27 \mathrm{~A}$ & $2,73 \mathrm{~A}$ & $4 \mathrm{~A}$ & $9,89 \mathrm{~A}$ \\
& $\mathrm{~B}$ & $\mathrm{~B}$ & $\mathrm{~b}$ & $\mathrm{a}$ \\
$2 \mathrm{~g} / \mathrm{L}$ & $1,62 \mathrm{~A}$ & $2,62 \mathrm{~A}$ & $2,98 \mathrm{~A}$ & $3,99 \mathrm{~B}$ \\
& $\mathrm{a}$ & $\mathrm{a}$ & $\mathrm{a}$ & $\mathrm{a}$ \\
$3 \mathrm{~g} / \mathrm{L}$ & $0,97 \mathrm{~A}$ & $1,47 \mathrm{~A}$ & $2,49 \mathrm{~A}$ & $3,19 \mathrm{~B}$ \\
& $\mathrm{~A}$ & $\mathrm{~A}$ & $\mathrm{a}$ & $\mathrm{a}$ \\
\hline
\end{tabular}

Keterangan: Angka yang diikuti huruf berbeda menunjukkan hasil yang berbeda nyata pada UJD $\alpha 5 \%$. Huruf kapital dibaca vertikal (membandingkan konsentrasi auksin yang sama). Huruf non kapital dibaca horizontal (membandingkan konsentrasi pupuk daun yang sama)

Notes: Numbers followed by different letters show significantly different results at Duncan a 5\%. Capital letter in vertical read (compare the same auxin concentration). Non capital letter in horizontal read (compare the same foliar fertilizer concentration)

Bobot kering tanaman dapat menunjukkan kemampuan tanaman dalam mengambil unsur hara untuk menunjang pertumbuhan dan aktivitas metabolisme di dalam jaringan tanaman (Susilo, 2019). (Priangga et al., 2013) juga menyatakan bahwa tinggi rendahnya bobot kering tanaman tergantung dari jumlah serapan 
unsur hara oleh akar tanaman yang berlangsung selama proses pertumbuhan. Terlihat dari Gambar 3 bahwa kombinasi perlakuan terbaik yaitu pada Gambar 3A karena dapat menghasilkan bobot kering tanaman tertinggi apabila dibandingkan dengan perlakuan lainnya. (Wahyudin \& Irwan, 2019) menyatakan bahwa pemberian pupuk yang memiliki kandungan nitrogen dalam hal ini seperti halnya komposisi pada pupuk daun yang digunakan, membuat tanaman mampu meningkatkan laju fotosintesis. Hasil fotosintesis tersebut berupa akumulasi karbohidrat yang tersedia bagi pertumbuhan tanaman yang disimpan di dalam jaringan tanaman selama masa hidupnya yang nantinya setelah tanaman dikeringkan akan meningkatkan nilai bobot keringnya.

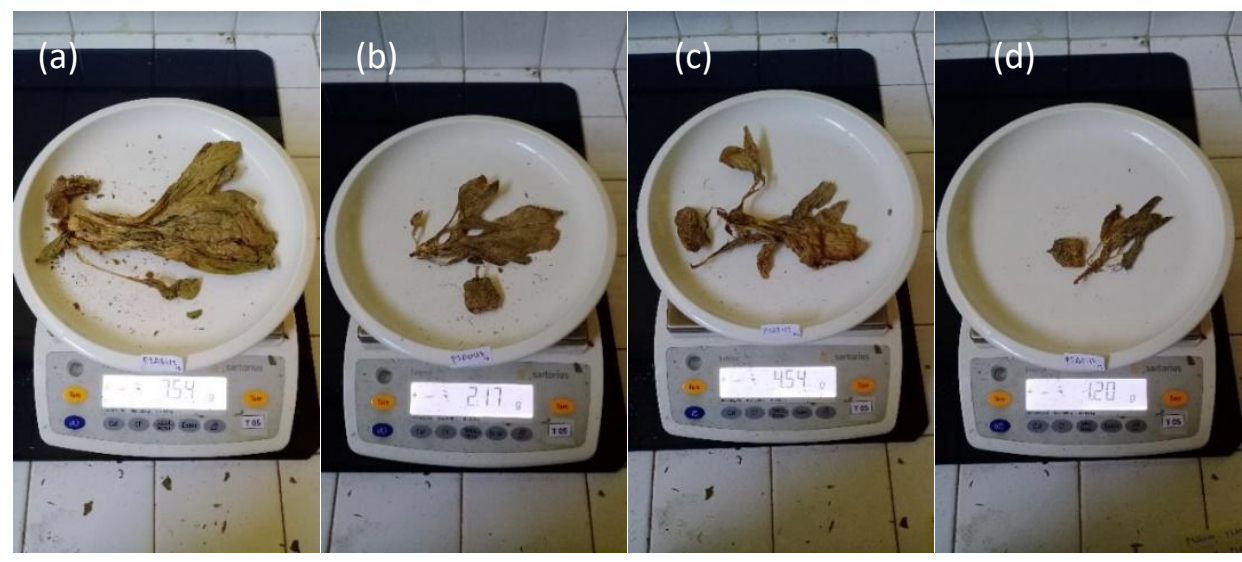

Gambar 3. Bobot kering pada empat perlakuan berbeda. Figure 3. Dry weight in four different treatments.

Keterangan:

(a). Kombinasi Perlakuan Konsentrasi Pupuk Daun $1 \mathrm{~g} / \mathrm{L}$ dan auksin Auksin $3 \mathrm{ml} / \mathrm{L}$,

(b). Kombinasi Perlakuan Konsentrasi Pupuk Daun $1 \mathrm{~g} / \mathrm{L}$ dan auksin Auksin $0 \mathrm{ml} / \mathrm{L}$,

(c). Kombinasi Perlakuan Konsentrasi Pupuk Daun 3 g/L dan auksin Auksin 3 ml/L,

(d). Kombinasi Perlakuan Konsentrasi Pupuk Daun 3 g/L dan auksin Auksin 0 ml/L.

Notes:

(a). Combination Treatment of Foliar Fertilization Concentration $1 \mathrm{~g} / \mathrm{L}$ and Plant Growth Regulators Concentration $3 \mathrm{ml} / \mathrm{L}$,

(b). Combination Treatment of Foliar Fertilization Concentration $1 \mathrm{~g} / \mathrm{L}$ and Plant Growth Regulators Concentration $0 \mathrm{ml} / \mathrm{L}$,

(c). Combination Treatment of Foliar Fertilization Concentration $3 \mathrm{~g} / \mathrm{L}$ and Plant Growth Regulators Concentration $3 \mathrm{ml} / \mathrm{L}$,

(d). Combination Treatment of Foliar Fertilization Concentration $3 \mathrm{ml} / \mathrm{L}$ and Plant Growth Regulators Concentration $0 \mathrm{ml} / \mathrm{L}$.

\section{Laju Pertumbuhan}

Laju pertumbuhan tanaman dapat diamati melalui pertambahan tinggi tanaman pada setiap minggunya. Interaksi pemberian kombinasi konsentrasi pupuk daun $1 \mathrm{~g} / \mathrm{L}$ dengan auksin $3 \mathrm{ml} / \mathrm{L}$ (P1A3) memberikan rerata laju pertumbuhan tertinggi yaitu sebesar 7,74 dari taraf lainnya. Menurut (Praba et al., 2009), laju pertumbuhan tanaman secara umum akan terlihat lambat di awal masa penanaman lalu akan meningkat pada saat fase vegetatif akhir dan akan menurun ketika telah mencapai batas maksimal pertumbuhan. Sedangkan perlakuan konsentrasi pupuk daun $3 \mathrm{~g} / \mathrm{l}$ dengan konsentrasi zat pengatur tumbuh $0 \mathrm{ml} / 1$ menghasilkan laju pertumbuhan terendah yaitu 0,33 . Interaksi antara konsentrasi 
pupuk daun dan konsentrasi zat pengatur tumbuh dapat dilihat pada Tabel 6.

Aplikasi pupuk daun dan zat pengatur tumbuh dengan konsentrasi yang tepat akan membantu dalam pertumbuhan tanaman pakcoy yang ditanaman secara akuaponik. Aplikasi pupuk daun $1 \mathrm{~g} / \mathrm{L}$ membuat pertumbuhan tanaman pakcoy menjadi lebih baik. Konsentrasi pupuk daun yang rendah sudah dapat memenuhi kebutuhan hara tanaman karena air limbah ikan lele telah mengandung hara makro dan mikro yang dibutuhkan oleh tanaman. Penambahan konsentrasi pupuk daun yang semakin tinggi mengakibatkan pertumbuhan tanaman terhambat karena hara yang diaplikasikan berlebih sehingga pertumbuhan tanaman menjadi terhambat. Pemberian pupuk daun yang berlebih akan berpengaruh tidak baik bagi tanaman, karena konsentrasi yang terlalu tinggi dimungkinkan akan merusak struktur kloroplas yang membuat sistem membran tilakoid dalam kloroplas akan mengalami perobekan (Mas' ud, 2009). Konsentrasi pupuk daun yang lebih tinggi dari $1 \mathrm{~g} / \mathrm{L}$ mengindikasikan adanya toksisitas karena kelebihan aplikasi pupuk daun. Aplikasi zat pengatur tumbuh akan efektif apabila kebutuhan hara telah tercukupi. Pemberian zat pengatur tumbuh dengan konsentrasi 3 $\mathrm{ml} / \mathrm{L}$ dapat meningkatkan pertumbuhan tanaman pakcoy yang dibudidayakan secara akuaponik. Pengaplikasian zat pengatur tumbuh dengan konsentrasi yang semakin tinggi akan meningkatkan kandungan hormon auksin yang dapat mendorong pertumbuhan di dalam jaringan tanaman sehingga akan berpengaruh terhadap pertumbuhan secara keseluruhan (Mutryarny \& Lidar, 2018).

Tabel 6. Pengaruh Konsentrasi Pupuk Daun dan Zat Pengatur Tumbuh Auksin Terhadap Laju Pertumbuhan

Table 6. Effect of Foliar Fertilization Concentration and Auxin Growth Regulatory Substance Concentration on Growth Rate

\begin{tabular}{ccccc}
\hline $\begin{array}{c}\text { Pupuk Daun } \\
\text { Foliar }\end{array}$ & \multicolumn{4}{c}{ ZPT Auksin/Auxin Growth Regulatory (A) } \\
\cline { 2 - 5 } Fertilization $(\mathrm{P})$ & $0 \mathrm{ml} / \mathrm{L}$ & $1 \mathrm{ml} / \mathrm{L}$ & $2 \mathrm{ml} / \mathrm{L}$ & $3 \mathrm{ml} / \mathrm{L}$ \\
\hline \multirow{2}{*}{$1 \mathrm{~g} / \mathrm{L}$} & $0,98 \mathrm{~A}$ & $1,35 \mathrm{~A}$ & $2,36 \mathrm{~A}$ & $7,74 \mathrm{~A}$ \\
& $\mathrm{~b}$ & $\mathrm{~b}$ & $\mathrm{~b}$ & $\mathrm{a}$ \\
$2 \mathrm{~g} / \mathrm{L}$ & $0,54 \mathrm{~A}$ & $1,27 \mathrm{~A}$ & $1,55 \mathrm{~A}$ & $2,35 \mathrm{~A}$ \\
& $\mathrm{a}$ & $\mathrm{a}$ & $\mathrm{a}$ & $\mathrm{a}$ \\
$3 \mathrm{~g} / \mathrm{L}$ & $0,33 \mathrm{~A}$ & $0,43 \mathrm{~A}$ & $1,17 \mathrm{~A}$ & $1,73 \mathrm{~B}$ \\
& $\mathrm{a}$ & $\mathrm{a}$ & $\mathrm{a}$ & $\mathrm{a}$ \\
\hline
\end{tabular}

Keterangan:Angka yang diikuti huruf berbeda menunjukkan hasil yang berbeda nyata pada UJD $\alpha$ 5\%. Huruf kapital dibaca vertikal (membandingkan konsentrasi auksin yang sama). Huruf non kapital dibaca horizontal (membandingkan konsentrasi pupuk daun yang sama)

Notes: Numbers followed by different letters show significantly different results at Duncan $\alpha 5 \%$.

Capital letter in vertical read (compare the same auxin concentration). Non capital letter in horizontal read (compare the same foliar fertilizer concentration)

\section{KESIMPULAN}

Pertumbuhan dan hasil tanaman pakcoy yang dibudidayakan menggunakan akuaponik rakit apung dapat ditingkatkan dengan adanya pemberian kombinasi konsentrasi pupuk daun dan auksin yang tepat. Pemberian kombinasi konsentrasi 
pupuk daun $1 \mathrm{~g} / \mathrm{L}$ dan auksin $3 \mathrm{ml} / \mathrm{L}$ memberikan pertumbuhan dan hasil terbaik serta dapat meningkatkan hasil sebesar 54,55\% dibandingkan dengan perlakuan lainnya.

\section{DAFTAR PUSTAKA}

Amiroh, A. (2016). Kajian Pertumbuhan 钢 dan Produksi Tomat (Solanum licopersicum Mill) Terhadap Zat Pengatur Tumbuh Pada Macam Konsentrasi dan Waktu Pemberian. SAINTIS, 8(1), 1-12.

Andriyeni, A., Firman, F., Nurseha, N., 镸 Zulkhasyni, Z., \& others. (2017). Study of macro nutrient potential from catfisth waste water as a source for organic fertiliser. Jurnal Agroqua: Media Informasi Agronomi Dan Budidaya Perairan, 15(1), 71-75.

Arifin, R. (2016). Bisnis Hidroponik Ala EQ Roni Kebun Sayur. AgroMedia.

Astuti, S., \& Larasati, W. A. (2019). 钢 Respon Tanaman Sawi Pakcoy (Brassica Rapa) Terhadap Larutan Hara (Kotoran Ikan) Pada Sistem Akuaponik. Konservasi Hayati, 15(1), 10-15.

Badan Ketahanan Pangan (2019). Laporan 尌 tahunan Badan Ketahanan Pangan tahun 2019. Jakarta: Kementerian Pertanian.

Badan Pusat Statistik (2013). Ringkasan 钢 eksekutif pengeluaran dan konsumsi penduduk Indonesia. Badan Pusat Statistik, Jakarta.

Badan Pusat Statistik (2019). Statistik 尌 tanaman sayuran dan buah-buahan semusim Indonesia 2018. Badan Pusat Statistik Indonesia.
Damanik, R., \& Siregar, L. A. M. (2015).

顽 Pengaruh Pemberian N 2, 4-D Terhadap Pertumbuhan dan Metabolisme Kalus Kedelai Pada Kondisi Hipoksida Secara Invitro. Jurnal Agroekoteknologi Universitas Sumatera Utara, 4(1), 107676.

Erdiansyah, I., Putri, S. U., \& 尌 Eliyatiningsih, E. (2021). Diversitas Arthropoda Pada Tanaman Cabai Transisi Organik Dengan Aplikasi Beart Methods (Beaauveria bassiana, Refugia Area, Trichoderma spp) Dan Budidaya Konvensional. Agrin, 24(2), 175-184.

Fauzi, A. R., \& others. (2019). Response of 咥 Pakcoy (Brassica rapa L.) to the treatment of Liquid Organic Fertilizer of Fisheries Waste. Jurnal Hortikultura Indonesia, 10(2), 94101.

Gumelar, W. R., Nurruhwati, I., \& others. (2017). Pengaruh Penggunaan Tiga Varietas Tanaman Pada Sistem Akuaponik Terhadap Konsentrasi Total Amonia Nitrogen Media Pemeliharaan Ikan Koi. Jurnal Perikanan Kelautan, 8(2).

Habiburrohman, H. (2018). Aplikasi 臸 Teknologi Akuaponik Sederhana Pada Budidaya Ikan Air Tawar Untuk Optimalisasi Pertumbuhan Tanaman Sawi (Brassica juncea L.). UIN Raden Intan Lampung.

Hailu, M., Chimdessa, M., \& Muthswamy, E. (2018). In Vitro Propagation of Selected Sugarcane (Saccharum Officinarum L.) Varieties (C 86-165 and C 86-12) Through Shoot Apical Meristem. Hort Agric, 3(1), 1-7.

Iswanto, H. (2002). Petunjuk perawatan anggrek. AgroMedia. 
Junia, L. S., \& others. (2017). Uji

琶 Pertumbuhan Dan Hasil Tanaman Pakcoy (Brassica Rapa L.) Dengan Pemberian Pupuk Organik Cair Pada System Hidroponik. Agrifor, 16(1), $65-74$

Latarang, B., \& Syakur, A. (2006).

钢 Pertumbuhan dan hasil bawang merah (Allium ascalonicum L.) pada berbagai dosis pupuk kandang. Agroland: Jurnal Ilmu-Ilmu Pertanian, 13(3), 265-269.

Lestari, B. L. (2011). Kajian ZPT atonik 钢 dalam berbagai konsentrasi dan interval penyemprotan terhadap produktivitas tanaman bawang merah (Allium ascolanicum L.). Rekayasa, 4(1), 33-37.

Lingga, P. (2001). Petunjuk penggunaan 镐 pupuk. Niaga Swadaya.

Manurung, F. S., Nurchayati, Y., \& Setiari, 睌 N. (2020). Pengaruh pupuk daun Gandasil D terhadap pertumbuhan, kandungan klorofil dan karotenoid tanaman bayam merah (Alternanthera amoena Voss.). Jurnal Biologi Tropika, 1(1), 24-32.

Mas' ud, H. (2009). Sistem hidroponik 钢 dengan nutrisi dan media tanam berbeda terhadap pertumbuhan dan hasil selada. Media Litbang Sulteng, 2(2).

Mutryarny, E., \& Lidar, S. (2018). Respon

钢 Tanaman Pakcoy (Brassica rapa L) Akibat Pemberian Zat Pengatur Tumbuh Hormonik. Jurnal Ilmiah Pertanian, 14(2), 29-34.

Nurmala, T. (2003). Pengaruh Aplikasi 尌 Atonik 6, 5 L Terhadap Efisiensi Konversi Karbohidrat Pada Tanaman Serealia (Padi Gogo, Jagung, Sorghum) di Jatinangor. Bionatura,
$5(3)$.

Pakpahan, F. E., Azizah, N., \& Sudiarso, S. E (2018). Pengaruh Berbagai Konsentrasi ZPT Atonik Pada Pertumbuhan Berbagai Asal Batang Stek Sirih Merah (Piper crocatum Ruiz and Pav.). Jurnal Produksi Tanaman, 6(6).

Praba, M. L., Cairns, J. E., Babu, R. C., \& Eafitte, H. R. (2009). Identification of physiological traits underlying cultivar differences in drought tolerance in rice and wheat. Journal of Agronomy and Crop Science, 195(1), 30-46.

Pramita, Y., Wandansari, N. R., Salim, A., EQ Laksono, A. (2019). Aplikasi pupuk organik dan zat pengatur tumbuh dalam peningkatan produktivitas tanah dan tanaman. UNEJ E-Proceeding.

Priangga, R., \& Suwarno \& Hidayat, N. 到 (2013). Pengaruh level pupuk organik cair terhadap produksi bahan kering dan imbangan daun-batang rumput gajah defeliosi keempat. Jurnal Ilmiah Peternakan, 1(1), 365373.

Rahmadhani, L. E., Widuri, L. I., \& 到 Dewanti, P. (2020). Kualitas mutu sayur kasepak (kangkung, selada, dan pakcoy) dengan sistem budidaya akuaponik dan hidroponik. Jurnal Agroteknologi, 14(01), 33-43.

Sastro, Y. (2015). Akuaponik: Budidaya 喕 Tanaman Terintegrasi Dengan Ikan, Permasalahan Keharaan dan Strategi Mengatasinya. Buletin Pertanian Perkotaan, 5(1), 33-42.

Sholeha, W., Sugiharto, B., Setyati, D., \& EQ Dewanti, P. (2015). Induction somatic embryogenesis used 2, 4- 
dichlorophenoxyacetic acid (2, 4-D) and kinetin in spindle leaf explant sugarcane. Jurnal ILMU DASAR, 16(1), 17-22.

Siregar, M. (2018). Respon Pemberian 尌 Nutrisi Abmix pada Sistem Tanam Hidroponik Terhadap Pertumbuhan dan Produksi Tanaman Sawi (Brassica Juncea). Jasa Padi, 2(02), $18-24$.

Susilo, I. B. (2019). Pengaruh Konsentrasi 尌 dan Interval Waktu Pemberian Pupuk Organik Cair Terhadap Hasil Tanaman Pakcoy (Brassica rapa L.) dengan Sistem Hidroponik DFT. Berkala Ilmiah Pertanian, 2(1), 3441.

Sutanto, T. (2015). Rahasia Sukses

僉 Budidaya Tanaman dengan Metode Hidroponik. Bibit Publisher.

Vivonda, T., Yoseva, S., \& others. (2016). 尌 Optimalisasi Pertumbuhan Dan Produksi Tanaman Pakcoy (Brassicca Rapal) Melalui Aplikasi Beberapa Dosis Pupuk Bokashi. Riau University.

Wahyudin, A., \& Irwan, A. W. (2019). 钢 Pengaruh dosis kascing dan bioaktivator terhadap pertumbuhan dan hasil tanaman sawi (Brassica juncea L.) yang dibudidayakan secara organik. Kultivasi, 18(2), 899-902. 